\title{
BALANCED SCORECARD DALAM INSTITUSI PENDIDIKAN LANJUT
}

\author{
Budi Tiara Novitasari \\ Program Studi Akuntansi, Fakultas Ekonomi \\ Universitas Negeri Yogyakarta \\ budi.tiara@uny.ac.id
}

\begin{abstract}
Abstrak: Balanced Scorecard dalam institusi pendidikan lanjut. Balanced scorecard tidak hanya dikenal sebagai alat pengukur kinerja multidimensional yang menggabungkan aspek keuangan dan keuangan dalam organisasi akan tetapi juga dikenal sebagai sistem stratejik manajemen yang terintegrasi. Berbagai literatur dan penelitian terdahulu telah menganalisa penerapan dan peran balanced scorecard dalam organisasi. Kemampuan balanced scorecard untuk menggabungkan aspek keuangan dan aspek non-keuangan memberikan kesempatan untuk penerapan yang lebih jauh dalam organisasi non-profit, salah satunya adalah institusi pendidikan. Berbeda dengan entitas bisnis lain, penting bagi institusi pendidikan untuk turut memasukkan 3 fungsi utamanya yang meliputi, pengajaran dan pembelajaran, penelitian dan pengabdian masyarakat ke dalam pengukuran kinerjanya. Paper ini bertujuan untuk memaparkan hasil penelitian terdahulu terhadap penerapan dan pengembangan balanced scorecard dalam institusi pendidikan. Dengan memaparkan bagaimana fungsi institusi pendidikan dapat dipaparkan dalam perspektif balanced scorecard, paper ini diharapkan mampu memberikan gambaran dan acuan bagi penerapan balanced scorecard dalam institusi pendidikan.
\end{abstract}

Kata kunci: balanced scorecard, kinerja, perguruan tinggi

Abstract: Balanced Scorecard in higher education institution. Balanced scorecard as one of multidimensional performance measurement is known to be able to combine financial and non-financial aspect in assessing organization's performance. In addition to its role as performance measurement instrument, it is also known for its function as an integrated strategic management system. Previous researchers and literatures have been analyzing the implementation and role of balanced scorecard in various business organization. Its success story has inspired the use of balanced scorecard in public sector organizations including higher education institution. Its ability to combine both financial and non-financial aspect is expected to bring betterment for higher education institution by allowing the performance measurement process to include the three main functions of a higher education institution, namely teaching and learning, research and community service. This paper is aimed to provide overview on the implementation and development of balanced scorecard in higher education institution. It is expected that this paper can provide reference for future researchers on possible issues and topics for further research.

Keywords: balanced scorecard, performance, higher education institution

\section{PENDAHULUAN}

Pengukuran kinerja dalam organisasi memberikan kesempatan kepada personel organisasi untuk mengukur sejauh mana pencapaiannya, mengevaluasi capaian dan meningkatkan capaian di masa mendatang. Terdapat banyak metode yang dapat diadopsi untuk mengukur kinerja organisasi. Salah satu diantaranya adalah balanced scorecard. Balanced scorecard sebagai alat pengukuran kinerja memungkinkan organisasi untuk tidak hanya mengevaluasi kinerja dari sisi keuangan tetapi juga sisi non-keuangan (Hoque, 2003). Dengan demikian, 


\section{JURNAL NOMINAL / VOLUME VIII NOMOR 2 / TAHUN 2019}

memberikan gambaran yang lebih menyeluruh terkait capaian organisasi. Tidak hanya berperan sebagai instrumen pengukuran kinerja, balanced scorecard dalam perkembangannya turut berperan dalam meningkatkan proses perencanaan, komunikasi dan penerapan rencana strategis (Kaplan, 2010).

Berbagai organisasi bisnis telah mengadopsi balanced scorecard sebagai instrumen pengukuran kinerja sekaligus penerapan rencana strategis. Balanced scorecard memungkinkan organisasi untuk melihat hubungan sebab akibat dari seluruh kegiatan organisasi (Al-Hosaini \& Sofian, 2015). Dengan demikian organisasi bisnis mampu menganalisa hubungan sebab akibat dari aspek keuangan dan non-keuangan dalam operasi organisasi. Seiring dengan popularitasnya, organisasi non-profit mulai melirik balanced scorecard sebagai instrumen pengukur kinerja yang mampu mengakomodasi aspek non-keuangan yang menjadi fokus dari organisasi non-profit.

Institusi pendidikan tinggi merupakan salah satu bentuk dari organisasi non-profit yang dituntut untuk selalu berkembang seiring dengan perkembangan zaman dan teknologi. Zangoueinezhad \& Moshabaki (2011) menegaskan bahwa institusi pendidikan tinggi adalah salah satu dari area bisnis yang menghadapi perubahan kondisi bisnis yang sangat cepat. Perkembangan ekonomi dan globalisasi menuntut institusi pendidikan tinggi untuk memfokuskan diri pada kinerja organisasi secara kseluruhan termasuk di dalamnya adalah alokasi sumberdaya yang terbatas serta peningkatan kualitas dan manajemen layanan (AlZwyalif, 2012).

Akan tetapi, dengan instrument pengukuran kinerja yang belum mampu mencakup aspek keuangan dan nonkeuangan, institusi pendidikan tinggi masih mengalami kesulitan untuk beradaptasi dengan perubahan lingkungan yang sangat cepat. Griggs, Blackburn \& Smith (2012) menambahkan bahwa instrumen pengukuran kinerja yang dipergunakan dalam institusi pendidikan tinggi belum mampu mencakup keseluruhan nilai bisnis institusi pendidikan sekaligus mencakup berbagai perspektif para stakeholder sehingga institusi pendidikan tinggi tidak mampu menunjukkan nilai kinerja sesungguhnya. Dalam penelitiannya, Brown (2012) menggarisbawahi bahwa masih banyak institusi pendidikan yang terjebak dalam pengukuran kuantitatif atas variable akademiknya saja dalam mengukur kinerja institusi secara keseluruhan.

Menghadapi kondisi yang senantiasa berubah serta terbatasnya sumber daya yang dimiliki menuntut institusi pendidikan tinggi untuk menemukan solusi. Karathanos \& Karathanos (2005), Griggs, Blackburn \& Smith (2012), dan Brown

(2012) 


\section{JURNAL NOMINAL / VOLUME VIII NOMOR 2 / TAHUN 2019}

menjelaskan bahwa penerapan balanced scorecard dalam institusi pendidikan tinggi serta instusi pemerintahan lainnnya dalam membantu meningkatkan kinerja. Brown (2012) menjelaskan bahwa balanced scorecard dapat menjadi strategi perusahaan berdasarkan sistem manajemen yang mampu membantu institusi pendidikan untuk mengklarifikasi visi dan misinya serta menerjemahkan visinya kedalam strategi yang nyata. Selain itu, balanced scorecard juga mampu membantu institusi pendidikan tinggi untuk mengalokasikan sumber dayanya yang terbatas secara strategis dengan lebih baik (Chen, Yang \& Shiau, 2006).

Dalam perkembangannya, semakin banyak institusi pendidikan tinggi yang mengadaptasi balanced scorecard sebagai instrument pengukuran kinerja. Werasooriya (2013) menambahkan bahwa penerapan balanced scorecard turut dipengaruhi oleh faktor lingkungan eksternal entitas beroperasi, prioritas tiap entitas turut mempengaruhi pembentukan dan perkembangan kerangka balanced scorecard yang diterapkan oleh tiap institusi pendidikan tinggi. Artikel ini mengulas bagaimana balanced scorecard diterapkan dan dikembangkan dalam berbagai institusi pendidikan tinggi yang berbeda dengan konteks yang berbeda pula. Artikel ini diharapkan mampu berkontribusi dengan memberikan kajian mengenai penerapan dan pengembangan balanced scorecard dalam mengukur kinerja di berbagai institusi pendidikan tinggi untuk mendukung penerapan balanced scorecard di institusi pendidikan tinggi Indonesia sekaligus memberikan tambahan pengetahuan untuk kepentingan penelitian di masa mendatang.

\section{KAJIAN LITERATUR}

Balanced scorecard adalah salah satu sistem pengukuran kinerja yang tidak hanya berfokus pada aspek keuangan akan tetapi juga turut mempertimbangkan aspek nonkeuangan dalam sebuah organisasi (Hoque, 2003). Dikenalkan oleh Kaplan dan Norton pada tahun 1992, balanced scorecard meliputi empat perspektif yang berbeda dalam mengukur kinerja (Karathanos \& Karathanos, 2005; Kaplan, 2009; dan Hoque, 2003). Kaplan (2009) menjelaskan bahwa keempat perspektif dalan balanced scorecard bersifat saling mendukung satu dengan yang lain dalam usaha untuk mencapai tujuan jangka panjang organisasi. Keempat perspektif balanced scorecard meliputi perspektif keuangan, perspektif pelanggan, perspektif internal bisnis dan perspektif pembelajaran dan pertumbuhan.

Perspektif keuangan dalam entitas bisnis dapat diartikan sebagai nilai entitas di mata pemegang saham. Dalam entitas bisnis perspektif keuangan dapat diukur dengan 


\section{JURNAL NOMINAL / VOLUME VIII NOMOR 2 / TAHUN 2019}

mengacu pada pendapatan operasional, ROI, pendapatan bersih dan lain sebagainya (Hoque, 2003). Dalam penerapannya di entitas pemerintahan dan institusi pendidikan tinggi, perspektif keuangan mengacu pada pengukuran kinerja dan capaian target sehubungan dengan penggunaan sumber daya yang dimiliki, peningkatan nilai shareholder dan tingkat kembalian modal (Reda, 2017). Perspektif pelanggan mengukur kinerja entitas berdasarkan sudut pandang pelanggan yang dapat diukur dari kepuasan pelanggan, tingkat penggunaan ulang dan lain sebagainya. Jika dalam entitas bisnis pelanggan mengacu pada pengguna produk atau jasa yang dijual atau diproduksi, maka dalam instusi pendidikan pelanggan mengacu pada mahasiswa, orang tua wali, pengguna lulusan serta masyarakat dalam menggunakan produk organisasi (Reda, 2017). Perspektif internal bisnis dalam entitas bisnis mengacu pada kemampuan entitas untuk mengatur dan mengendalikan proses bisnisnya untuk mencapai tujuan yang telah ditetapkan. Hoque (2003) menjelaskan bahwa dalam entitas bisnis perspektif proses bisnis internal dapat dinilai dari design sebuah produk atau jasa, pengembangan produk atau jasa, efisiensi dan efektifitas proses produksi dan lain sebagainya. Dalam institusi pendidikan, proses bisnis internal mengacu pada proses belajar mengajar, penelitian serta pengabdian masyarakat (Reda, 2017). Perspektif yang terakhir adalah perspektif pembelajaran dan pertumbuhan yang mengacu pada upaya entitas atau institusi untuk selalu berkembang dengan meningkatkan kualitas sumber daya manusia, informasi dan modal organisasi yang dimiliki (Hoque, 2003 \& Kaplan, 2010).

Penerapan balanced scorecard dalam instusi memerlukan serangkaian langkah persiapan. Persiapan tersebut terdiri dari penentuan tim penyusun kerangka balanced scorecard yang melibatkan berbagai pihak di dalam organisasi, pengidentifikasian key performance indicator (KPI), proses pendefinisian dan review KPI, penetapan tolak ukur, target dan nilai sinyal dan penentuan design dari display balanced scorecard (Lyddon \& McComb, 2008). Dalam menyusun kerangka balanced scorecard penting untuk mengidentifkasi kegiatan - kegiatan yang akan dinilai dan kategori perspektif mana yang sesuai untuk golongan kegiatan tersebut. Setelah itu, penting untuk menentukan KPI yang dapat mengkuantifikasikan capaian dari kegiatan tersebut. Biasanya jumlah KPI dalam balanced scorecard berkisar antara $15-20$ 25, tidak disarankan untuk memiliki KPI yang terlalu banyak ataupun terlalu sedikit karena KPI diharapkan merupakan "kunci" ukuran yang sesungguhnya (Lyddon \&McComb, 2008 dan Arzamastseva \& Khayrullina, 2017). 


\section{JURNAL NOMINAL / VOLUME VIII NOMOR 2 / TAHUN 2019}

Selain berperan sebagai instrument pengukuran kinerja, balanced scorecard juga mampu berperan sebagai sistem manajemen (Lyddon \& McComb, 2008 dan Brown, 2012) serta alat komunikasi (Lyddon \& McComb, 2008). Ukuran - ukuran yang dipergunakan dalam setiap perspektif balanced scorecard menjadi alat komunikasi dari atasan kepada staff dan juga kepada pemegang kepentingan eksternal (shareholder dan stakeholder). Al-Hosaini \& Sofian (2015) menambahkan bahwa balanced scorecard mampu membantu institusi pendidikan tinggi untuk mentranformasikan visi, misi dan strateginya kedalam KPI yang nantinya dapat dipergunakan oleh manajemen dan staf sebagai alat komunikasi. Hal tersebut membantu memastikan seluruh perangkat yang ada dalam institusi pendidikan memiliki pemahaman yang selaras mengenai visi, misi dan strategi yang diterapkan. Dengan demikian, diharapkan mampu membantu proses pencapaian tujuan organisasi. Bread (2009) turut menambahkan bahwa balanced scorecard merangkum data terkait kinerja di masa sekarang sekaligus pendorong terciptanya kinerja di masa mendatang sehingga memungkinkan entitas bisnis yang menerapkannya mampu mengevaluasi kinerja secara lebih menyeluruh.

\section{METODE PENELITIAN}

Paper ini disusun dengan melakukan kaji literatur terhadap penelitian terdahulu mengenai balanced scorecard dan penerapannya dalan institusi pendidikan tinggi. Melalui kaji literatur, hasil penelitian mengenai penerapan balanced scorecard dalam institusi pendidikan tinggi dikumpulkan untuk membangun pemahaman mengenai bagaimana balanced scorecard diterapkan dan berkembang dalam institusi pendidikan tinggi.

\section{HASIL PENELITIAN DAN \\ PEMBAHASAN}

Balanced scorecard mulai banyak diimplementasikan dalam berbagai institusi pendidikan tinggi di berbagai belahan dunia. Meskipun demikian, terdapat perbedaan antara implementasi dari satu insititusi pendidikan tinggi yang satu dengan yang lain. Hal tersebut diantaranya disebabkan oleh perbedaan lingkungan eksternal serta tujuan dari tiap institusi pendidikan tinggi. Perbedaan tersebut beragam mulai dari bagaimana setiap institusi menerjemahkan dan memodifikasi perspektif balanced scorecard hingga sejauh mana balanced scorecard telah diterapkan sebagai instrument pengukur kinerja. Studi terdahulu tidak hanya melakukan penelitian empiris terhadap penerapan balanced scorecard tetapi juga memberikan saran mengenai 
rancangan balanced scorecard yang dapat diterapkan dalam institusi pendidikan tinggi.

Bread (2009) dalam studinya melaporkan bagaimana 2 universitas telah sukses menerapkan balanced scorecard sebagai instrument pengukuran kinerja dan telah mendapatkan pengakuan dari Malcolm Baldridge National Quality Award atas kesuksesannya. Dalam studinya, Bread menjelaskan bahwa Malcolm Baldridge National Quality Award menginisiasi adaptasi balanced scorecard untuk meningkatkan daya saing entitas bisnis di Amerika Serikat. Untuk kepentingan institusi pendidikan tinggi, balanced scorecard dimodifikasi sedemikian rupa dan menghasilkan 5 kategori utama yang meliputi:

1. Hasil belajar mahasiswa yang didasarkan berbagai metode evaluasi yang menggambarkan tujuan institusi pendidikan tinggi yang bersangkutan dan peningkatan capaian. Dalam struktur balanced scorecard klasik kategori ini mewakili perspektif pelanggan.

2. Output yang terfokus pada mahasiswa dan stakeholder lainnya yang terkait. Kategori ini meliputi pengukuran terhadap program pendidikan yang ditawarkan, pelayanan yang diberikan termasuk transaksi yang terjadi antara institusi pendidikan dan mahasiswa atau stakeholder. Dalam struktur balanced scorecard klasik kategori ini mewakili perspektif pelanggan.

3. Anggaran dan keuangan yang turut mencakup pengeluaran rutin, besarnya iuran yang dibayarkan mahasiswa, sumber pendanaan, beasiswa dan lain sebagainya. Dalam struktur balanced scorecard klasik kategori ini mewakili perspektif keuangan.

4. Output terkait dengan staf akademik dan staf pendukung lainnya yang mencakup inovasi, program pengembangan karyawan yang diterapkan, peningkatan kinerja, kepuasan karyawan, dan lain sebagainya. Dalam struktur balanced scorecard klasik kategori ini mewakili perspektif pembelajaran dan pertumbuhan.

5. Output terkait dengan tata kelola dan tanggung jawab sosial yang mencakup akuntabilitas fiskal secara internal ataupun eksternal, pengukuran terhadap etika dari semua pihak pihak yang terkait dalam institusi pendidikan tinggi, ketaatan terhadap hukum dan lain - lain. Kategori ini merupakan tambahan terhadap struktur klasik balanced scorecard dan merepresentasikan 
perspektif tata kelola dan tanggung jawab sosial.

Hasil dari studi ini menunjukkan bahwa kedua universitas yang mendapatkan penghargaan dari Malcolm Baldridge National Quality Award, yaitu University of Wisconsin dan Kenneth W. Monfort College of Business, menunjukkan bahwa keduanya menggunakan 5 kategori yang sama sesuai dengan yang telah dianjurkan oleh Malcolm Baldridge National Quality Award untuk menerapkan balanced scorecard. Akan tetapi, jika dilihat lebih jauh maka masing masing institusi pendidikan tinggi tersebut menggunakan pengukuran yang berbeda untuk mengukur tiap - tiap kategori yang dipergunakan. Perbedaan tersebut menggambarkan perbedaan misi, nilai dan visi yang diterapkan oleh masing - masing institusi. Meskipun demikian, di akhir studinya Bread (2009) menyimpulkan bahwa pengukuran kinerja dengan menggunakan KPI yang dihubungkan dengan perencanaan strategis telah memberikan manfaat kepada University of Wisconsin dan Kenneth W. Monfort College of Business untuk melakukan perbaikan kinerja yang sifatnya berkesinambungan.

\section{Griggs， Blackburn \& Smith (2012)} menganalisa model pengukuran kinerja pada institusi pendidikan tinggi dengan melakukan perbandingan metode antar beberapa universitas dan menganalisa sejauh mana stakeholder turut diikutsertakan dalam proses pengukuran kinerja. Dalam studinya, Griggs, Blackburn \& Smith (2012) menjelaskan bahwa model pengukuran kinerja yang saat ini dipergunakan masih belum mampu menunjukkan nilai sesungguhnya dari proses pembelajaran yang dilalui dan belum mampu untuk menyajikan penilaian dari berbagai perspektif stakeholder. Berdasarkan hasil perbandingan metode pengukuran kinerja yang dilakukan pada studi tersebut, ditemukan bahwa meskipun menggunakan istilah yang berbeda, sebagian besar universitas masih mempergunakan instrument yang sama untuk mengukur kinerja yaitu dengan menggunakan kuesioner untuk mengukur kepuasan mahasiswa di akhir semester. Meskipun demikian, Griggs, Blackburn \& Smith (2012) berpendapat bahwa pengukuran dengan metode tersebut cenderung memberikan gambaran atas perspektif mahasiswa terhadap pembelajaran dan dosen dan kurang mampu menggambarkan proses pembelajaran yang sesungguhnya. Oleh karena itu, hasilnya lebih sesuai dipergunakan untuk mengembangkan pengajaran dan performa dosen akan tetapi kurang komprehensif jika tujuan utamanya adalah untuk meningkatkan output institusi pendidikan tinggi. Selain itu, hasil studi juga menunjukkan bahwa dalam melakukan evaluasi, universitas yang termasuk sebagai sample penelitian telah 


\section{JURNAL NOMINAL / VOLUME VIII NOMOR 2 / TAHUN 2019}

mengikutsertakan beberapa perspektif stakeholder akan tetapi evaluasi yang dilakukan belum mampu menghubungankan antara perspektif yang satu dengan yang lain.

Berdasarkan hasil penelitiannya, Griggs, Blackburn \& Smith (2012) mengajukan saran bagi institusi pendidikan tinggi untuk menggunakan balanced scorecard yang dilabeli dengan nama baru yaitu educational scorecard untuk mengukur kinerjanya secara lebih komprehensif. Educational scorecard yang diajukan memodifikasi struktur klasik balanced scorecard untuk memenuhi kebutuhan institusi pendidikan tinggi yang berbeda dengan entitas bisnis pada umumnya. Perspektif educational scorecard meliputi perspektif mahasiswa, perspektif universitas dan badan professional, perspektif pengajaran, dan perspektif pembelajaran dan pertumbuhan.

Hladchenko (2014) membandingkan penerapan balanced scorecard pada tiga institusi pendidikan tinggi Jerman (Johanes Gutenberg University Mainz, Munster University of Applied Sciences, dan Cologne University of Applied Sciences) dan satu institusi pendidikan tinggi Austria (Montan University Leoben). Dalam studinya, ditegaskan bahwa sebagai insitusi non-profit, institusi pendidikan tinggi memiliki produk keluaran yang tidak dapat dilihat secara langsung serta pengukuran kinerja berbasis pada aspek keuangan dianggap tidak cukup komprehensif untuk memberikan penilaian kinerja secara keseluruhan. Berdasarkan hasil penelitian, pada seluruh institusi pendidikan tinggi yang diteliti pengembangan balanced scorecard dilakukan dengan melibatkan perwakilan dari seluruh lapisan organisasi. Sehingga proses pengembangan tersebut turut melibatkan pimpinan institusi, pimpinan fakultas serta pimpinan dari departemen yang bersangkutan. Kerumitan dalam penyusunan dan pengembangan balanced scorecard membuat Jonaes Gutenberg University Mainz untuk bekerja sama dengan konsultan manajemen professional.

Berdasarkan hasil penelitian yang dilakukan oleh Hladchenko (2014) ketiga insitusi pendidikan tinggi yang memiliki struktur balanced scorecard yang berbeda antara satu dengan yang lainnya. Dalam proses pengembangannya, ketiga institusi pendidikan tinggi tersebut melakukan modifikasi pada empat struktur klasik balanced scorecard yang terdiri dari perspektif keuangan, pelanggan, proses bisnis internal, dan pembelajaran dan partumbuhan. Munster University of Applied Sciences memiliki balanced scorecard yang terdiri dari perspektif pendidikan (education) yang menggantikan pelanggan, pespektif penelitian (research) yang menggantikan proses bisnis internal, dan perspektif sumber daya (resources) yang terdiri dari staf, 


\section{JURNAL NOMINAL / VOLUME VIII NOMOR 2 / TAHUN 2019}

keuangan, infrastruktur dan manajemen menggantikan perspektif pembelajaran dan pertumbuhan serta keuangan. Johanes Gutenberg University Mainz melakukan modifikasi dengan tetap mempertahankan perspektif keuangan dan menggantikan perspektif pelanggan dengan perspektif tugas, perspektif proses bisnis internal dengan pelayanan, dan perspektif pembelajaran dan pertumbuhan dengan pespektif potensi. Cologne University of Applied Sciences mempertahankan perspektif pelanggan dan proses bisnis internal akan tetapi memodifikasi perspektif pembelajaran dan pertumbuhan menjadi perspektif potensial dan perspektif keuangan menjadi perspektif sumber daya. Sample penelitian yang terakhir yaitu Montan University Leoben memiliki 5 perspektif berbeda dengan ketiga sampel yang lain. Perspektif Montan University Leoben terdiri dari perspektif kinerja, perspektif proses, perspektif stakeholder, perspektif potensial dan perspektif keuangan. Hlandchenko (2014) menggarisbawahi bahwa kesuksesan penerapan balanced scorecard pada institusi pendidikan tinggi ditentukan oleh partisipasi sampai dengan tingkat fakultas dalam proses penyusunannya. Selain itu, Hlandchenko (2014) juga menemukan bahwa terlepas dari manfaat yang ditawarkan oleh penerapan balanced scorecard, dalam penelitian ini manfaatnya belum dapat secara total dirasakan karena para kurangnya pengalaman dan pemahaman para manajer di dalam institusi pendidikan tinggi dalam pengembangan dan penerapan balanced scoreacard.

Novitasari (2015) melakukan penelitian terhadap penerapan balanced scorecard pada divisi pengembangan karakter di International Program, Universitas Islam Indonesia. Keempat struktur klasik balanced scorecard yang terdiri dari perspektif pelanggan, proses bisnis internal, pembelajaran dan pertumbuhan, dan keuangan diterapkan untuk mengukur kinerja divisi pengembangan karakter. Novitasari (2015) menggarisbawahi hasil penelitiannya bahwa KPI dari tiap perspektif belum semuanya tersusun dengan baik dan tidak semua staf yang terkait memahami penerapan dari instrument pengukuran kinerja.

Reda (2017) dalam studinya menggarisbawahi peranan balanced scorecard dalam menjaga kualitas institusi pendidikan tinggi sekaligus menyarankan model balanced scorecard yang sesuai dengan konteks institusi pendidikan tinggi. Dalam studinya Reda menggarisbawahi pentingnya memastikan bahwa penerapan balanced scorecard harus mampu mendukung proses peningkatan kualitas institusi pendidikan tinggi yang fungsi utamanya terdiri dari pengajaran dan pembelajaran, penelitian dan pengabdian 


\section{JURNAL NOMINAL / VOLUME VIII NOMOR 2 / TAHUN 2019}

masyarakat. Oleh karena itu, untuk memudahkan proses pengukuran kinerja penjaminan dibagi menjadi dimensi input, proses dan output. Shabani et al., (2014) dalam Reda (2017) menjelaskan secara mendetail apa yang termasuk dalam input, proses dan output. Input dalam model penjaminan mutu institusi pendidikan tinggi meliputi mahasiswa, pengajar, tenaga akademik dan administratif, manajer, kurikum, fasilitas, keuangan dan materi pengajaran. Proses meliputi proses pengajaran dan pembelajaran yang terjadi, proses penelitian, waktu dan ruang yang dipergunakan, layanan untuk mahasiswa, keterlibatan dalam kegiatan komunitas masyarakat, dan pengelolaan institusi pendidikan tinggi. Output meliputi lulusan yang memiliki kemampuan yang disyaratkan dan diinginkan oleh bursa kerja, masyarakat luas, serta kontribusi institusi pendidikan tinggi terhadap perkembangan ekonomi dan sosial serta pengetahuan. Dalam model balanced scorecard yang disarankan dalam studi yang dilakukan oleh Reda (2017) perspektif pelanggan berhubungan dengan dimensi output, perspektif keuangan berhubungan dengan dimensi proses dan input, perspektif proses bisnis internal berhubungan dengan dimensi proses, dan perspektif pembelajaran dan pertumbuhan berhubungan dengan aspek input.
Arzamastseva \& Khayrullina (2017) dalam risetnya pada institusi pendidikan tinggi di Rusia merancang balanced scorecard yang sesuai untuk mendukung institusi pendidikan tinggi ditengah persaingan internasional untuk memperebutkan ranking internasional. Dengan menganalisa model penilaian empat ranking internasional yang terdiri dari Quacquarelly Symonds (QS) World University Ranking, Times Higher Educatonal World University Ranking (THE), Academic Ranking of the World Universities (ARWU) dan Webometrics, dan juga model penilaian pemeringkat Rusia yang ditujukan untuk universitas dan instansi pendidikan tinggi lainnya, Arzamastseva \& Kyarullina (2017) merumuskan empat area yang menjadi fokus utama dalam pemeringkatan dan persaingan global antar institusi pendidikan tinggi di dunia. Keempat area tersebut terdiri dari pendidikan, penelitian dan kegiatan inovatif lainnya, kegiatan internasional, dan lingkungan kewirausahaan.

Dengan mempertimbangkan tujuan strategis yang berfokus pada pemenangan kompetisi internasional dengan mempromosikan keunggulan lokal, Arzamastseva \& Kyarullina (2017) memformulasikan balanced scorecard yang terdiri dari 4 perspektif yang dikenal dengan perspektif keuangan perspektif pelanggan, 


\section{JURNAL NOMINAL / VOLUME VIII NOMOR 2 / TAHUN 2019}

perspektif proses bisnis internal dan prespektif kapasitas. Keempat perspektif balanced scorecard yang diajukan dalam riset ini mencakup empat area yang menjadi fokus utama dalam penilaian kualitas institusi pendidikan tinggi dalam persaingan global. Perspektif keuangan yang diajukan oleh Arzamastseva \& Kyarullina (2017) memberikan perubahan berupa mengukur kemampuan institusi pendidikan untuk mendapatkan dana tambahan dari berbagai kesempatan hibah serta bantuan nasional dan internasional lainnya. Perspektif pelanggan mendefinisikan pelanggan dalam institusi pendidikan tinggi sebagai mahasiswa atau lulusan, orang tua mahasiswa, bisnis pengguna lulusan serta para peneliti. Perspektif proses bisnis internal mewakili efektifitas dan efisiensi isntitusi pendidikan tinggi dalam menjalankan fungsi dan operasionalnya. Perspektif yang terakhir yaitu kapasitas mengacu pada kinerja, kepuasan serta upaya peningkatan kualitas sumber daya manusia yang ada di dalam lingkungan institusi pendidikan tinggi dalam menjalankan tugas profesionalnya.

Penelitian terdahulu menunjukkan bahwa dalam penerapan balanced scorecard institusi pendidikan tinggi dapat melakukan modifikasi terhadap struktur klasik balanced scorecard berdasarkan visi, misi dan tujuan masing - masing institusi. Berbeda dengan penerapan balanced scorecard pada entitas bisnis yang berorientasi pada keuntungan, penerapan balanced scorecard pada institusi pendidikan tinggi dimodifikasi untuk dapat mengukur kinerja sesuai dengan fungsi institusi pendidikan tinggi yang sebenarnya yaitu terkait dengan funsginya sebagai penyedia layanan pendidikan, pengembang penelitian sekaligus sebagai pengabdi masyarakat. Kesuksesan penerapan balanced scorecard turut dipengaruhi oleh proses perencanaan yang sempurna dan melibatkan seluruh komponen organisasi dan pemahaman mengenai penerapannya. Tabel 1 berikut memberikan rangkuman mengenai penerapan balanced scorecard dalam institusi pendidikan tinggi pada penelitian terdahulu yang dibahas dalam artikel ini.

Tabel 1: Penerapan Balanced Scorecard Dalam Institusi Pendidikan Tinggi

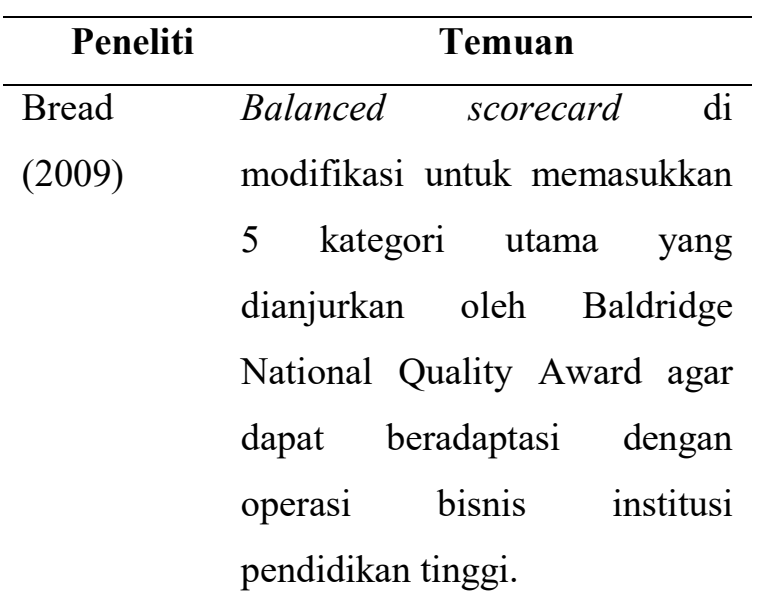


JURNAL NOMINAL / VOLUME VIII NOMOR 2 / TAHUN 2019

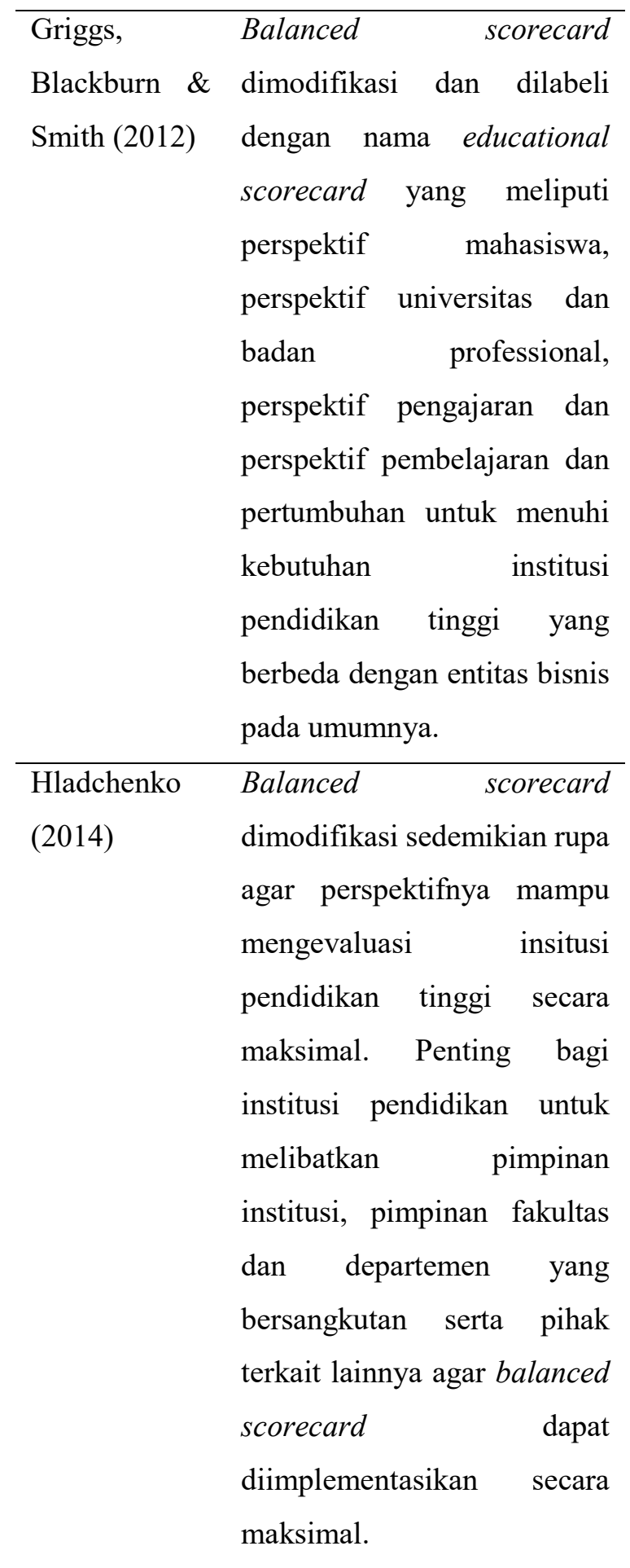

\begin{tabular}{ll}
\hline Novitasari & Key Performance lindex pada \\
(2015) & penerapan balance scorecard \\
& dari tiap perspektif belum \\
& tersusun secara sempurna dan \\
& tidak semua staf terkait \\
& memiliki pemahaman yang \\
& sama mengenai penerapan \\
& balanced scorecard sebagai \\
& instrument pengukuran \\
& kinerja. \\
\hline Proses pengukuran kinerja \\
menjadi tiga dimensi yaitu \\
dimensi input, proses dan \\
output. Perspektif pelanggan \\
berhubungan dengan dimensi \\
output, perspektif keuangan \\
berhubungan dengan dimensi \\
proses dan input, perspektif \\
proses binis internal \\
berhubungan dengan dimensi \\
proses dan perspektif \\
pembelajaran \\
pertumbuhan berhubungan \\
dengan aspek input. \\
\hline (2017) \\
\end{tabular}


JURNAL NOMINAL / VOLUME VIII NOMOR 2 / TAHUN 2019

\begin{tabular}{ll}
\hline Arzamastseva & Permasalahan yang diahadapi \\
\& Khayrullina & dalam penerapan balance \\
s017) & porecard dalam institusi \\
& Dendidikan yaitu: \\
& sorecard di universitas \\
& terdapat tiga masalah utama. \\
& Pertama, kegiatan di \\
& universitas berfokus pada \\
& kegiatan akademis, berbeda \\
& dengan sektor bisnis. Kedua, \\
& pada universitas lebih banyak \\
& mengevaluasi hal - hal yg \\
& bersifat kualitatif. Ketiga, \\
& tidak mengaitkan balanced \\
& scorecard dengan tujuan \\
& stategis.
\end{tabular}

\section{SIMPULAN DAN SARAN}

Balanced scorecard sebagai instrument pengukuran kinerja yang mampu menggabungkan perspektif keuangan dan non-keuangan secara bersamaan telah memberikan kesempatan bagi institusi pendidikan tinggi untuk lebih jauh menilai kinerjanya secara komprehensif. Untuk dapat mengukur kinerja institusi pendidikan tinggi dengan baik, balanced scorecard dimodifikasi untuk dapat mencakup fungsi utama institusi pendidikan tinggi yaitu pengajaran, penelitian dan pengabdian masyarakat serta menyesuaikan dengan visi, misi dan tujuan dari masing - masing institusi (Bread, 2009; Griggs, Blackburn \& Smith, 2012; Hladchenko, 2014; Reda, 2017;
Arzamastseva \& Kyarullina, 2017). Kesuksesan penerapan balanced scorecard mensyaratkan proses perencanaan yang seksama dan melibatkan seluruh perwakilan organisasi untuk meningkatkan pemahaman dan keakuratan pengukuran yang dipergunakan dalam setiap perspektifnya (Hladchenko, 2014).

\section{DAFTAR PUSTAKA}

Al-Hosaini, F. F., \& Sofian, S. (2015). A review of balanced scorecard framework in higher education institusion. International Review of Management and Marketing. 5(1). 26 -35 .

Al-Zwyalif, I. M. (2012). The possibility of implementing balance scorecard in Jordanian private universities. International Business Research. 5 (11).

Arzamastseva, M. \& Khayrullina, M. (2017). Problems of implementing a balanced scorecard as a management tool in universities. CBU International Conference on Innovations in Science and Education. doi: http://dx.doi.org/10/12955/cbup.v5.8 $\underline{92}$

Beard, D. F. (2009). Successful application of the balanced scorecard in higher education. Missouri: Heldref publication.

Brown, C. (2012). Aplication of the balance scorecard in higher education: Oportunities and challenges. Society for College and University Planning.

Chavan, M. (2007). The balanced scorecard: A new challenge. Journal of Management Development. 28 (3), $393-406$. 


\section{JURNAL NOMINAL / VOLUME VIII NOMOR 2 / TAHUN 2019}

Chen, Yang \& Shiau, (2006). The application of balance scorecard in the performance evaluation of higher education. The TQM Magazine. 18 (2).

Griggs, Blackburn \& Smith. (2012). The educational scorecard: The start of our journey. Electroninc Journal of Business Research Method. 10 (2).

Hladchendko, M. (2014). Balanced scorecard: A strategic management system of the higher education institution. International Journal of Education Management. 29 (2), 167 -176 .

Hoque, Z. (2003). Strategic management accounting ( $2^{\text {nd }}$ ed.). Australia: Pearson.

Kaplan. R. S. (2009). Conceptual foundations of the balanced scorecard. Handbook of Management Accounting Research. 3.

Karathanos, D \& Karathanos, P. (2005). Aplying the balanced scorecard to education. Journal of Education for Business. 80 (4). 222.

Lyddon, J. W., \& McComb, B. E. (2008). Strategic reporting tool: Balanced scorecards in higher education. Journal of Applied Research on the Community College. 15 (2), 163 170.

Novitasari, B. T. (2015). An investigation on the balanced scorecard implementation in evaluating and developing character building program in international program, Universitas Islam Indonesia (Thesis yang tidak dipublikasikan). Universitas Negeri Sebelas Maret.

Reda, N. (2017). Balanced scorecard in higher education institutions: Congruence to, and role in quality assurance practices. Quality
Assurance in Education. 25 (4), 489 499.

Weerasooriya, W. M. R. B. (2013). Adoption the balanced scorecard (BSC) framework as a technique for performance evaluation in Sri Lankan Universities. doi: http://dx.doi.org/10.2139/ssrn.22239 $\underline{33}$

Zangoueinezhad, A. \& Moshabaki, A. (2011). Measuring university performance using a knowledgebased balanced scorecard. International Journal of Productivity and Performance Management. 60 (8), $824-843$. 